\title{
Cdc37 is a molecular chaperone with specific functions in signal transduction
}

\author{
Yoko Kimura, ${ }^{1}$ Suzanne L. Rutherford, ${ }^{1}$ Yoshihiko Miyata, ${ }^{2}$ Ichiro Yahara, ${ }^{2}$ Brian C. Freeman, ${ }^{3}$ \\ Lin Yue, ${ }^{1}$ Richard I. Morimoto, ${ }^{3}$ and Susan Lindquist ${ }^{1,4}$ \\ ${ }^{1}$ Howard Hughes Medical Institute, and Department of Molecular Genetics and Cell Biology, The University of Chicago, \\ Chicago, Illinois 60637 USA; $^{2}$ Department of Cell Biology, The Tokyo Metropolitan Institute of Medical Science, Tokyo \\ 113, Japan; ${ }^{3}$ Department of Biochemistry, Molecular Biology and Cell Biology, Northwestern University, \\ Evanston, Illinois 60208 USA
}

$\mathrm{Cdc} 37$ is required for cyclin-dependent kinase activation and is genetically linked with the activity of several other kinases, including oncogenic v-Src, casein kinase II, MPS-1 kinase, and sevenless. Strikingly, many pathways involving Cdc37 also involve the protein chaperone Hsp90. The identification of $\mathrm{Cdc} 37$ as the 50-kD protein in several Hsp90-kinase complexes, together with other data, led to the recent suggestion that Cdc37 is a kinase-targeting "subunit" of Hsp90. We directly examined the effect of Cdc37 on Hsp90 functions. Rather than simply acting as an accessory factor for $\mathrm{Hsp} 90, \mathrm{Cdc} 37$ is itself a protein chaperone with properties remarkably similar to those of $\mathrm{Hsp90}$. In vitro, Cdc37 maintains denatured $\beta$-galactosidase in an activation-competent state without reactivating it and stabilizes mature, but unstable, casein kinase II. In vivo, Cdc37 overexpression can compensate for decreased Hsp90 function, but the proteins are not interchangeable. Cdc37 can compensate for $\mathrm{Hsp90}$ in maintaining the activity of v-Src kinase but does not maintain the activity of the glucocorticoid receptor. Thus, the very similar chaperone activities of the two proteins, uncovered through in vitro analysis, diverge in vivo in specific signal transduction pathways.

[Key Words: Cdc37; Hsp90; chaperone; kinase; signal transduction]

Received April 3, 1997; revised version accepted May 27, 1997.

CDC37 was first identified as a gene required for progression through the cell division cycle in Saccharomyces cerevisiae (Reed 1980; Ferguson et al. 1986). The $\mathrm{Cdc} 37$ protein is structurally unrelated to other proteins, and its functions have been enigmatic; however, its role in the cell cycle is now understood by its action on cyclin-dependent kinases (CDKs). In both $S$. cerevisiae and Drosophila melanogaster, Cdc37 interacts genetically with key regulators of the cell cycle, the $\mathrm{Cdc} 28 / \mathrm{Cdc} 2$ CDKs (Reed et al. 1985; Cutforth and Rubin 1994). In yeast $c d c 37$ mutants, $\mathrm{Cdc} 28$ does not form signaling complexes with cyclins, and its activity and accumulation are impaired (Gerber et al. 1995).

Cdc37 functions are not restricted to the cell cycle. Several genetic screens link Cdc37 with unrelated signaling pathways and kinases. For example, cdc37 mutants suppress the toxic effects of the oncogenic kinase of Rous sarcoma virus, v-Src, when it is expressed in yeast (Dey et al. 1996). CDC37 is also a high-copy suppressor of temperature-sensitive mutations in two dissimilar yeast kinases, casein kinase II (CKII) (R. McCann, D. Hanna, and C. Glover, pers. comm.) and MPS1 kinase

${ }^{4}$ Corresponding author.

E-MAIL s-lindquist@uchicago.edu; FAX (773) 702-7254.
(Schutz et al. 1997). In Drosophila, Cdc37 mutants were isolated in a genetic screen for critical limiting components in signaling by the sevenless receptor tyrosine kinase (Cutforth and Rubin 1994).

It is striking that many of the signaling pathways in which $\mathrm{Cdc} 37$ functions also involve the protein chaperone Hsp90. For example, mutations in Hsp90 reduce both the stability and activity of V-Src kinase, suppressing its toxicity to yeast (Xu and Lindquist 1993). Hsp90 also interacts with casein kinase II, protecting it from inactivation in vitro (Miyata and Yahara 1992, 1995), and Drosophila Hsp90 mutants (Hsp83) were isolated in the same sevenless screen that generated Cdc37 mutants (Cutforth and Rubin 1994).

These observations suggest that $\mathrm{Cdc} 37$ and $\mathrm{Hsp} 90$ are functionally allied. Very recent data place $\mathrm{Cdc} 37$ in complexes with some of the same targets as Hsp90. The mammalian cell cycle regulator $\mathrm{Cdk} 4$ coimmunoprecipitates with Cdc37 and Hsp90 (Dai et al. 1996; Stepanova et al. 1996). More tellingly, Cdc37 is now known to be p50 (Stepanova et al. 1996), a protein found previously with several Hsp90 targets, including Rafl (Stancato et al. 1993; Wartmann and Davis 1994), v-Src (Brugge et al. 1981; Whitelaw et al. 1991), and the Src-family kinases Fyn, Yes, Fps, Fes, Lck, and Fgr (Brugge 1986; Ziemieki et 
al. 1986; Hartson and Matts 1994; Nair et al. 1996). $\mathrm{Cdc} 37$ may be required for kinase recognition by Hsp90; $\mathrm{Cdc} 37$ must be coexpressed with $\mathrm{Cdk} 4$ in insect cells to detect an association between $\mathrm{Hsp} 90$ and the kinase (Stepanova et al. 1996). Based on these data, W. Harper and associates postulate that $\mathrm{Cdc} 37$ is a subunit of Hsp90 that targets the chaperone to specific kinases (Stepanova et al. 1996).

Hsp90 chaperones the maturation and maintenance of diverse signal transducers, including tyrosine and serine/ threonine kinases and transcription factors of both the steroid hormone receptor and basic helix-loop-helix classes. It interacts with these targets in conjunction with a group of at least eight associated chaperones and cofactors (for review, see Smith 1993; Smith and Toft 1993; Bohen and Yamamoto 1994; Jakob and Buchner 1994; Rutherford and Zuker 1994). The Hsp90 chaperone pathway is dynamic and the proteins associated with Hsp90 were originally thought to vary for different targets. It now seems likely that the entire array interacts with most targets (Nair et al. 1996). The notable exception is $\mathrm{Cdc} 37 / \mathrm{p} 50$, which has been found only in association with kinases (Brugge 1986; Whitelaw et al. 1991; Stancato et al. 1993; Nair et al. 1996).

The specific biochemical functions of Hsp90 in vitro are just being unraveled at this time. Although Hsp90 can promote the forward folding of some substrates under certain conditions (Shaknovich et al. 1992; Wiech et al. 1992; Jakob and Buchner 1994|, more commonly it does not. Rather, Hsp90 protects unstable substrates and folding intermediates from aggregation and inactivation (Miyata and Yahara 1992; Jakob et al. 1995; Freeman and Morimoto 1996); whether or not forward folding results from this interaction may depend on the substrate (Jakob et al. 1995). For example, Hsp90 maintains previously denatured $\beta$-galactosidase in a form competent for reactivation by conventional chaperones while not promoting reactivation itself (Freeman and Morimoto 1996). Hsp90 also protects CKII, a mature but unstable kinase that aggregates and loses activity rapidly in low salt buffers (Miyata and Yahara 1992, 1995). Similarly, Hsp90 protects purified citrate synthase from thermal denaturation and aggregation (Jakob et al. 1995). These maintenance functions of $\mathrm{Hsp} 90$ in vitro are reminiscent of a maintenance function described previously in vivo: Hsp90 is continuously required to maintain the glucocorticoid receptor in a state that is not yet active but can be activated readily by ligand (Nathan and Lindquist 1995).

Because Cdc37 and Hsp90 function in several of the same signal transduction pathways and associate with some of the same target proteins, we reasoned that they might function together. Therefore, we asked whether Cdc 37 would affect Hsp90 chaperone activity in these in vitro assays. Surprisingly, we find that $\mathrm{Cdc} 37$ is a molecular chaperone in its own right, with activities that are remarkably similar to those of Hsp90. Genetic analyses in both yeast and flies indicate that Cdc37 and Hsp90 are critical limiting factors for essential cellular processes. Nevertheless, Cdc37 and Hsp90 sometimes favor different substrates and, when interacting with the same substrate, may have different effects. Thus, in the same cell, proteins with very similar chaperone activities can have profoundly different biological effects.

\section{Results}

Cdc37 maintains denatured substrates in a reactivation-competent state

Yeast Cdc37 was overproduced in bacteria. As with native yeast $\mathrm{Cdc} 37$, the recombinant protein migrated as a $68-\mathrm{kD}$ band on Coomassie-stained gels, although its predicted molecular mass is $58.4 \mathrm{kD}$ (Fig. 1A). By molecularsieve chromatography, Cdc37 migrated as a $130-\mathrm{kD}$ species, suggesting that $\mathrm{Cdc} 37$, like Hsp90, is a dimer (Fig. 1B). In yeast, Hsp90 (Hsp82 and Hsc82) is both highly abundant, comprising $0.5 \%-1 \%$ of total protein, and heat-inducible (Borkovich et al. 1989). In contrast, Cdc37 represents only $\sim 0.01 \%$ of soluble yeast protein (data not shown) and was not induced by heat shock (Fig. 1C).

We first examined the effects of purified yeast Cdc37 on Hsp90 functions in vitro. The chaperone functions of Hsp90 have been established in large part by its ability to prevent the irretrievable aggregation of proteins transferred from denaturant into aqueous buffer (Wiech et al. 1992; Jakob et al. 1995; Freeman and Morimoto 1996). For example, Hsp90 maintains denatured $\beta$-galactosidase in an intermediate state-inactive but readily reactivated by the addition of other chaperones, Hsp70 and Hdjl (Fig. 2A,B; Freeman and Morimoto 1996). Cdc37 was added with Hsp90 (Hsp82) in these assays to test its effects on $\beta$-galactosidase maintenance (Fig. 2C). When
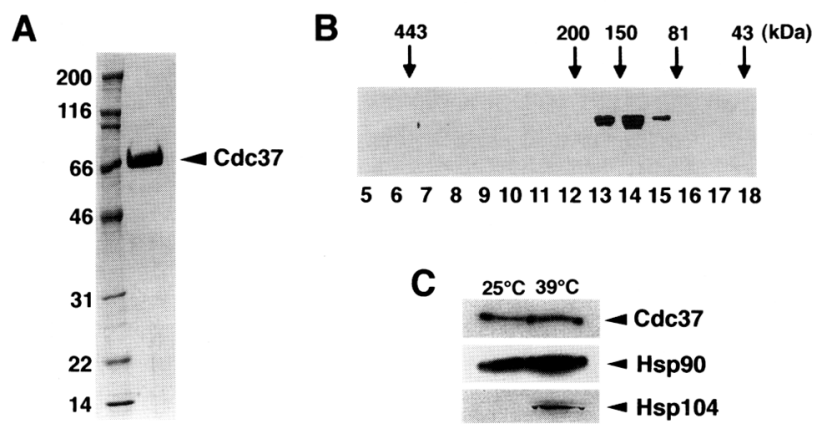

Figure 1. Characterization of Recombinant Cdc37. (A) By denaturing SDS-PAGE, purified recombinant Cdc37 $(2.5 \mu \mathrm{g})$ migrates at the position expected for a $68 \mathrm{kD}$ protein (arrowhead) and is the sole species detected by Coomassie blue staining. The positions of molecular mass standards are indicated. $(B)$ Under native conditions recombinant $\mathrm{Cdc} 37$ migrates at the position expected for a $130-\mathrm{kD}$ protein. Fractions from a Sephadex-200 gel filtration column were analyzed by SDS-PAGE. The peak fractions of molecular mass standards are indicated by arrows. (C) $\mathrm{Cdc} 37$ is not induced by heat. Total cellular proteins from yeast cells grown at $25^{\circ} \mathrm{C}$ or heat-shocked at $39^{\circ} \mathrm{C}$ for $45 \mathrm{~min}$ were separated by SDS-PAGE, blotted, and reacted sequentially with antibodies specific to $\mathrm{Cdc} 37$, Hsp90 (yeast Hsp/c82), and Hsp 104. Equal loading was verified by Coomassie blue staining prior to immunostaining. Hsp 90 is induced approximately 2 -fold by heat, and Hsp104 is induced more than 20-fold. 

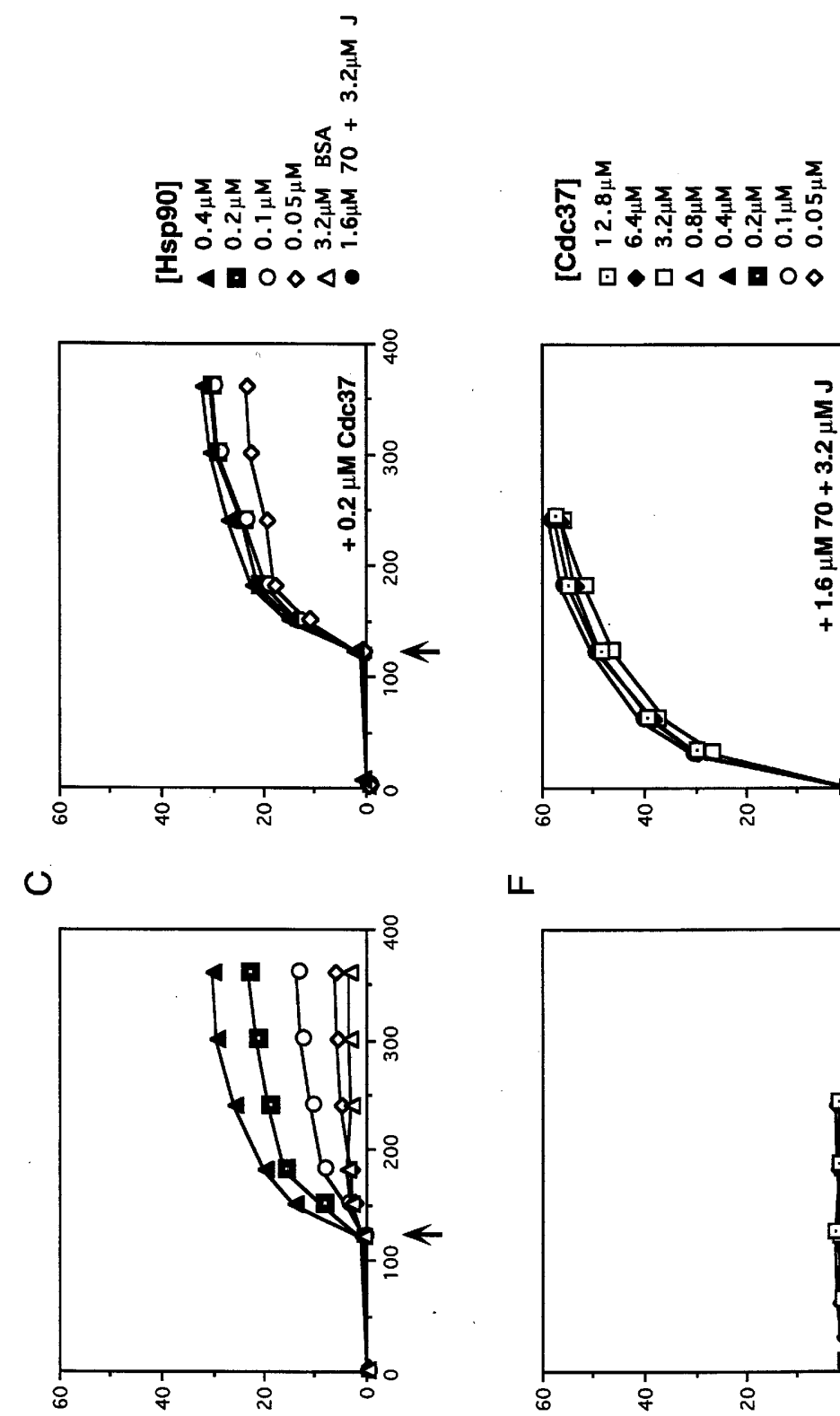

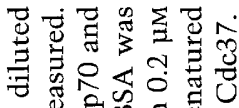

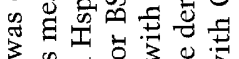

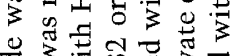

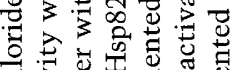

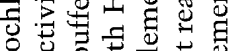

혀을

c

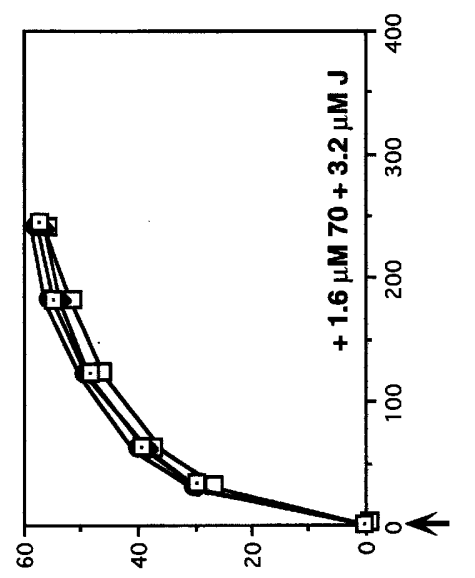

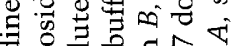

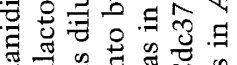

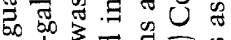

$\sum$ के 몽

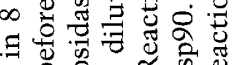

D

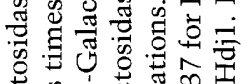

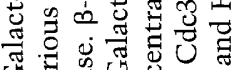

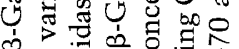

0 它

ชण

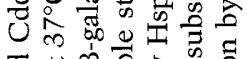

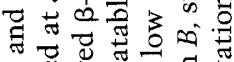

ᄂ

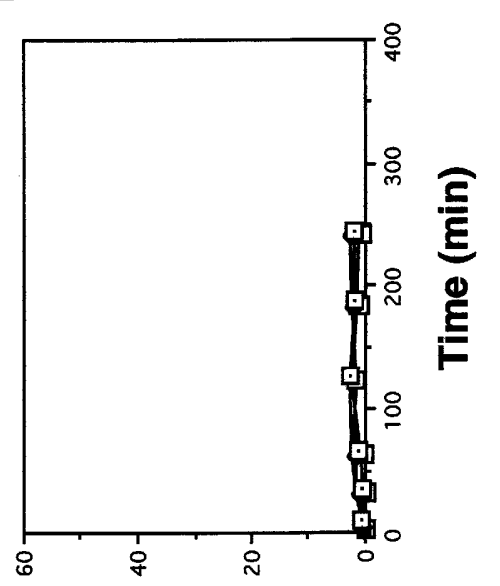

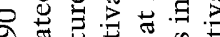

की

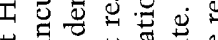

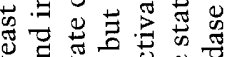

$\therefore \square$

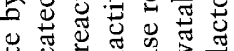

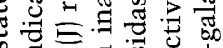

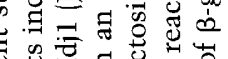

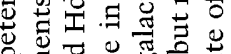

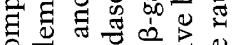

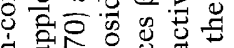

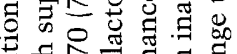

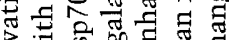

उ.

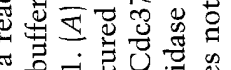

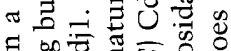

$\mathbf{m}$

ш
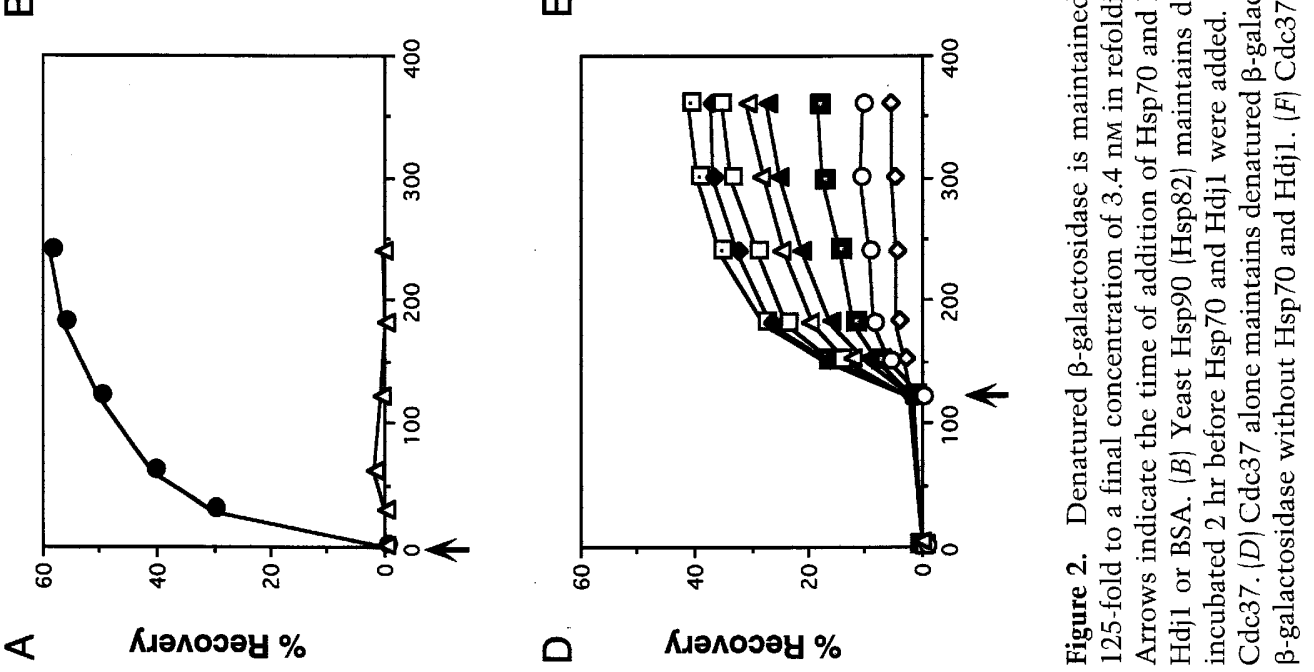
Hsp90 concentrations were low, Cdc37 increased the recovery of active $\beta$-galactosidase. Curiously, when the concentration of Hsp90 was increased just severalfold, the effects of Cdc37 on the yield and the rate of the reaction became negligible. More surprising, Cdc37 itself was as effective as Hsp90 in maintaining the enzyme in an activation-competent state (Fig. 2D). The kinetics of $\beta$-galactosidase reactivation were very similar for enzyme maintained by Hsp90 or $\mathrm{Cdc} 37$ (Fig. 2B,D); neither was affected by ATP (data not shown); and even at high concentrations, neither reactivated denatured $\beta$-galactosidase on its own (Fig. 2E). As reported for Hsp90, Cdc37 did not affect the rate of $\beta$-galactosidase reactivation when Hsp70 and Hdjl were present in the initial dilution buffer at optimal concentrations (Fig. 2F). Thus, Cdc37 independently chaperones non-native $\beta$-galactosidase in a manner different from Hsp70 and Hdjl but remarkably like Hsp90, and the combined effects of Hsp90 and Cdc37 appear simply additive. Separate experiments with firefly luciferase extended the similarity of Cdc37 and Hsp90 chaperone activities to a different denatured substrate (data not shown).

\section{Cdc37 stabilizes an inherently unstable kinase}

We also compared the chaperone activities of $\mathrm{Cdc} 37$ and Hsp90 on one of their natural substrates, CKII. CKII is biochemically associated with Hsp90 (Dougherty et al. 1987; Miyata and Yahara 1992, 1995) and genetically linked to Cdc37 (McCann and Glover 1995). Hsp90 chaperone functions with CKII have been established through its ability to maintain the already folded but unstable kinase in an active state. As shown previously (Miyata and Yahara 1992, 1995), when purified CKII was transferred to low salt buffer at $37^{\circ} \mathrm{C}$ for $60 \mathrm{~min}$, its kinase activity was largely lost (Fig. 3, lane 5). Cdc37 was as effective as Hsp90 (cf. lanes 6 and 7) in maintaining the activity of CKII. Neither purified Cdc37 nor Hsp90 contained kinase activity itself (Fig. 3, lanes 1-4) nor could either protein restore CKll activity after it was inactivated (data not shown). When $\mathrm{Hsp} 90$ and $\mathrm{Cdc} 37$ were supplied together, CKII activity was the same as with either chaperone alone (Fig. 3, lanes 6-8). When tested further over a broad range of concentrations, Cdc37 and Hsp90 exhibited similar concentration dependence for CKII maintenance, and their effects, when mixed, were additive rather than synergistic (data not shown). Thus, $\mathrm{Cdc} 37$ and Hsp90 exhibit very similar chaperone activity with three different substrates in vitro.

\section{Genetic interactions between Cdc37 and Hsp90: enhanced phenotypes in double mutants}

We turned to genetic analyses to investigate the similarity of $\mathrm{Cdc} 37$ and Hsp90 biological functions in vivo. First, we asked whether the proteins compensate for each other when the function of one or the other is impaired. A yeast strain ( $S$. cerevisiae) engineered to produce $\sim 10 \%$ wild-type Hsp90 levels ( $\Delta h s c 82$ ) (Borkovich et al. 1989) was crossed with an isogenic, temperature-

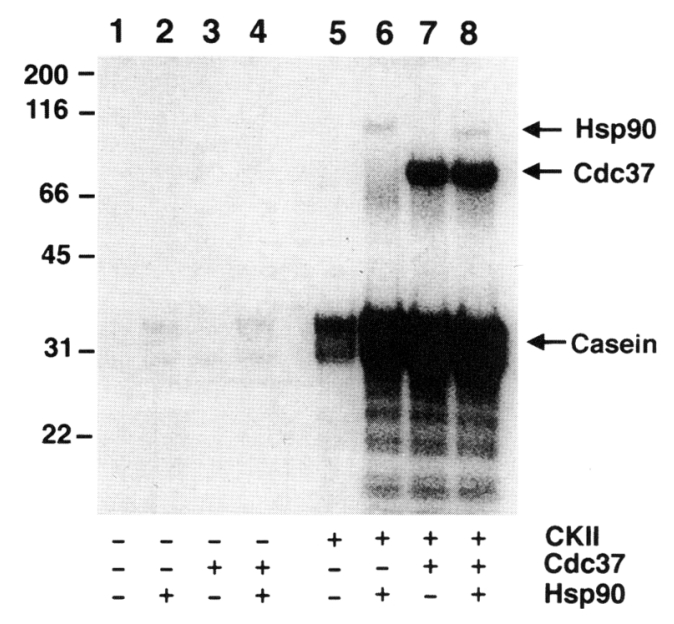

Figure 3. CKII is maintained in an active state by $\mathrm{Cdc} 37$ or Hsp90. In lanes 1-4, Hsp90 (1 $\mu \mathrm{M}), \mathrm{Cdc} 37(1 \mu \mathrm{M})$, or both proteins $\left(1 \mu \mathrm{M}\right.$ each) were incubated in low salt buffer at $30^{\circ} \mathrm{C}$ for 60 min. In lanes 5-8, duplicate reactions contained purified native CKII $(20 \mathrm{nM})$. Dephosphorylated casein and $\left[\gamma^{32} \mathrm{P}\right] \mathrm{ATP}$ were then added, and incubation was continued for an additional 30 min. Proteins were subjected to SDS-PAGE, and the incorporation of radioactive phosphate was visualized by autoradiography of the dried gel. The positions of $\mathrm{Hsp} 90, \mathrm{Cdc} 37$, and casein are marked.

sensitive Cdc37 mutant (cdc37-1; Reed 1980). Double mutant progeny $(\Delta h s c 82 c d c 37-1)$ produced pinpoint colonies at $25^{\circ} \mathrm{C}$, both initially and on restreaking, whereas their single-mutant parents and siblings grew at near wild-type rates (Fig. 4A). More remarkably, flies ( $D$. melanogaster) doubly heterozygous for certain recessive lethal alleles of $C d c 37$ (Cutforth and Rubin 1994) and Hsp83 (Drosophila Hsp90; isolated by Dickson et al. 1996) did not survive, even though they carried one wildtype copy of each gene (second-site noncomplementation; Table 1). These studies indicate that the normal activity of either gene compensates for decreased activity of the other and that the activities of both genes are limiting for the same critical cellular processes.

The extreme consequences to both yeast and flies of simultaneously reducing $\mathrm{Cdc} 37$ and Hsp90 functions demonstrates that the relationship between the two proteins is highly conserved. In vivo, when the function of one of the proteins is impaired, wild-type function of the other is required to compensate for normal growth. In vitro, the chaperone activities of the two proteins are nearly indistinguishable. We therefore tested whether the functions of these genes are so similar that they can completely substitute for each other in vivo.

\section{Genetic interactions between Cdc37 and Hsp90: the proteins are not interchangeable}

We first asked whether overexpression of Cdc37 in yeast could substitute for Hsp90 when Hsp90 function was reduced below the levels found in $\Delta h s c 82$ cells. In a yeast strain expressing even lower levels of Hsp90 that is extremely temperature sensitive for growth (iLEP), overex- 


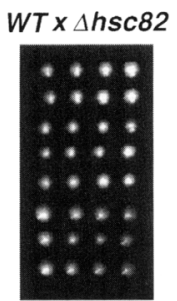

B
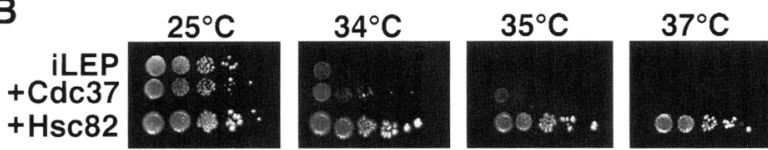

C
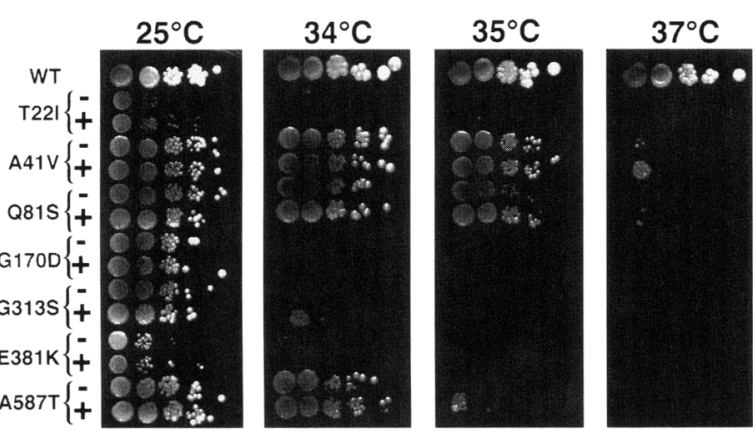

Figure 4. Genetic interactions between Hsp90 (Hsp82) and Cdc37 in yeast. $(A)$ Impaired growth of double mutants. An Hsp90 mutant, CLD82 (4hsc82), was crossed with either a wildtype strain, W303 (WT), or an isogenic $c d c 37-1$ strain $\left(c d c 37^{t s}\right)$. Diploids were sporulated and dissected, and the four haploid products of each tetrad were incubated for 3 days at $25^{\circ} \mathrm{C} .(B, C)$ $\mathrm{Cdc} 37$ overexpression provides only weak suppression of $\mathrm{Hsp} 90$ temperature-sensitive mutants. (B) An Hsp90 mutant producing wild-type Hsp90 at a very low level, iLEP1, was transformed with the vector alone, a Cdc37 overexpression plasmid (Cdc37), or an Hsp90 overexpression plasmid (Hsc82). (C) Hsp90 point mutants (T22I, A41V, Q81S, G170D, G313S, E381K, A587T) were transformed with either vector (-) or a Cdc37 overexpression plasmid $(+)$. All transformants were grown in SD media, and 10-fold serial dilutions were spotted on YPD plates and incubated for 2 to 4 days at the indicated temperatures. An Hsp90 expression plasmid completely rescued the temperaturesensitive phenotype of every strain ( $B$; data not shown).

pression of $\mathrm{Cdc} 37$ enhanced growth at semipermissive temperatures $\left(33^{\circ} \mathrm{C}\right)$ but did not allow growth above $35^{\circ} \mathrm{C}$ (Fig. 4B). When Cdc 37 was overexpressed in several different hsp82 point mutants, it enhanced growth in only a few of the mutants (A41V, G313S, and A587T; Fig. $4 \mathrm{C}$. Even for those alleles in which growth was enhanced, overexpression of $\mathrm{Cdc} 37$ did not extend the critical growth temperature very far.

In complementary experiments, we examined the ability of Hsp90 overexpression in yeast to compensate for mutant Cdc37. Hsc82 was overexpressed from a highcopy vector in $c d c 37-1$ cells. Although this vector reproducibly increased Hsp90 protein levels, the temperature sensitivity of the strain was not rescued (data not shown).

To extend this analysis to Drosophila, we tested whether supplementing the two endogenous copies of
Hsp90 with four additional copies of the Hsp90 gene would rescue the lethality of $C d c 37$ homozygotes, which die in embryogenesis and early larval stages, or $C d c 37$ heteroallelic mutant combinations, some of which die in late larval stages. Hsp90 and flanking genomic sequences carried in stable P-element insertions produced sufficient protein to rescue lethal Hsp83 homozygotes (S. Rutherford, unpubl.). However, they did not rescue homozygous $C d c 37$ mutants or heteroallelic $C d c 37 \mathrm{mu}-$ tant combinations (Table 2).

In these experiments, the allele-specific interactions between $\mathrm{Cdc} 37$ and Hsp90 in both yeast and flies reinforce the conclusion that Cdc37 functions are closely allied with those of Hsp90. However, the functions of the two proteins are not interchangeable. Despite the similarity of their chaperone functions in vitro, in vivo there must be an important distinction between the biological functions of the two proteins.

\section{Effect of $C d c 37$ on specific Hsp 90 targets in vivo}

We examined the ability of $\mathrm{Cdc} 37$ to substitute for Hsp90 in the maturation and maintenance of two of the best-characterized signaling targets of Hsp90, the oncogenic kinase v-Src (Brugge 1986; Whitelaw et al. 1991; Xu and Lindquist 1993) and the steroid-regulated transcription factor GR (glucocorticoid receptor; Smith 1993; Bohen and Yamamoto 1994). The Hsp90 chaperone pathway is highly conserved, and when these heterologous target proteins are expressed in yeast their activity depends on Hsp90 (Picard et al. 1990; Xu and Lindquist 1993; Bohen and Yamamoto 1994; Nathan and Lindquist 1995). As in vertebrate cells (Brugge 1986), Cdc37 and Hsp90 interact with v-Src in yeast (Fig. 5A). We did not detect a similar interaction with GR.

Mutations in either Cdc37 or Hsp90 suppress the toxicity of $\mathrm{v}$-Src by reducing its promiscuous tyrosine kinase activity, indicating that both proteins play a role in the activation of the kinase (Xu and Lindquist 1993; Dey et al. 1996). When expressed in the temperature-sensitive Hsp90 point mutant $h s p 82^{G 170 D}$, v-Src exhibited high kinase activity at $25^{\circ} \mathrm{C}$, but kinase activity was severely reduced at $34^{\circ} \mathrm{C}$, although cell viability remained high (Fig. 5B; Nathan and Lindquist 1995). A high-copy $\mathrm{Cdc} 37$ expression plasmid restored $v$-Src activity at $34^{\circ} \mathrm{C}$ (Fig. 5B). Interestingly, the phosphoprotein profile was altered. It may be that $\mathrm{Cdc} 37$ and Hsp90 influence interactions between the kinase and its substrates. Alternatively, they may have independent effects on the maturation of targets. In any case, $\mathrm{Cdc} 37$ was able to compensate for Hsp90 in promoting v-Src activity.

In contrast, the high-copy Cdc37 plasmid did not rescue GR activity in $h s p 82^{G 170 D}$, either at a semipermissive temperature (Fig. $6,33^{\circ} \mathrm{C}$ ) or at a nonpermissive temperature (Fig. 6, 35 ${ }^{\circ} \mathrm{C}$; Nathan and Lindquist 1995). Accumulation of GR was similar in all samples, and $\mathrm{Cdc} 37$ protein was overexpressed in cells containing the expression plasmid (Fig. 6B). A wild-type Hsp90 expression plasmid (HSC82) rescued GR activity in this strain (data not shown). Thus, when Hsp90 function is com- 
Kimura et al.

Table 1. Second-site noncomplementation between Cdc37 and Hsp 90 (Hsp83) mutants in Drosophila

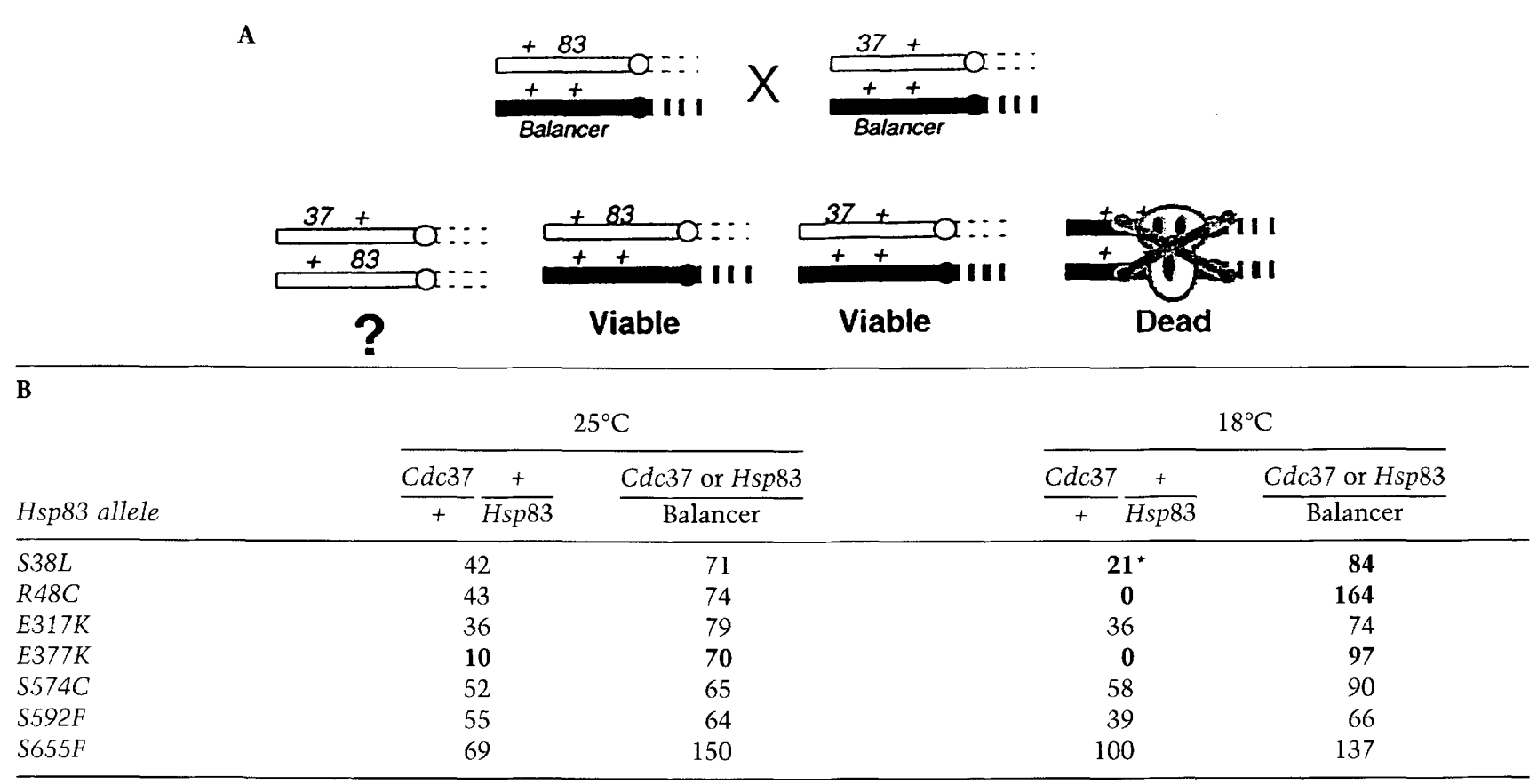

(A) The progeny from a cross between $H s p 83$ (83) and $C d c 37$ (37) balancer heterozygotes are expected in a 1:1:1:1 ratio. Solid bars designate balancer chromosomes that cover the lethality of the Hsp83 and Cdc37 alleles and carry dominant visible markers with recessive lethals (Lindsley and Zimm 1992). Double heterozygotes are identified by the lack of dominant markers that distinguish the balancer chromosomes. The balancer homozygotes from this cross die during embryogenesis because they contain recessive lethals. $(B)$ Loss-of-function Cdc37 alleles do not complement specific Hsp83 alleles. Shown are the results from crosses between females carrying different, balanced $H s p 83$ alleles and balanced $C d c 37^{e 4 D}$ males. Three $H s p 83$ alleles, $S 38 L, R 48 C$, and $E 377 K$, failed to complement $C d c 37^{e 4 D}$ (numbers in bold). Two alleles, $S 38 L$ and $R 48 \mathrm{C}$, were temperature-sensitive for this effect $\left(18^{\circ} \mathrm{C}\right.$ vs. $25^{\circ} \mathrm{C}$ ). Asterisks indicate double heterozygotes that either displayed developmental abnormalities (S38L) or died shortly after enclosing $(E 377 K)$. Reciprocal crosses gave similar results, as did crosses with $C d c 37^{e 1 E}$; however, the Cdc37 point mutant $C d c 37^{e 6 B}$ was viable in combination with all Hsp83 alleles (S. Rutherford and L. Yue, unpub.).

promised, overexpression of $\mathrm{Cdc} 37$ rescues the activity of $\mathrm{v}$-Src but not GR.

\section{Discussion}

The combination of in vitro and in vivo methods employed here provides new perspective on the functions of Cdc37. Genetic screens had uncovered a role for $\mathrm{Cdc} 37$ in diverse kinase-regulated signaling pathways, but Cdc37 might have operated in those pathways in many different capacities (e.g., as a kinase-targeting "subunit" or activator, as a phosphatase inhibitor, or as a scaffold for the association of other proteins). We demonstrate that in vitro $\mathrm{Cdc} 37$ can act as a molecular chaperone with properties remarkably like those of Hsp90. The chaperone character of $\mathrm{Cdc} 37$ revealed by these assays suggests alternative models for $\mathrm{Cdc} 37$ function (see below). Genetic analyses of $\mathrm{Cdc} 37$ function in vivo do not and cannot in themselves establish a chaperone activity for $\mathrm{Cdc} 37$, but they reveal a specificity in $\mathrm{Cdc} 37$ functions not apparent in the in vitro assays.
Maintenance vs. forward folding: Hsp 90 chaperone functions

The chaperone properties of Hsp90 currently provide the best foundation for understanding $\mathrm{Cdc} 37$ chaperone activity. Although Hsp90 functions have long been enigmatic, recently Hsp90 has become firmly established as a molecular chaperone (Shaknovich et al. 1992; Wiech et al. 1992; Jakob and Buchner 1994; Miyata and Yahara 1992; Jakob et al. 1995; Freeman and Morimoto 1996). Implicit in the early definition of the term chaperone was the notion that the prevention of off-pathway aggregation was coupled with increased folding (Ellis 1987). But Hsp90 and a growing class of other chaperones prevent aggregation without efficiently promoting forward folding by themselves (Jakob et al. 1995; Bose et al. 1996; Duina et al. 1996; Freeman and Morimoto 1996; Freeman et al. 1996). The importance of this activity in the concentrated intracellular milieu is easily understood, but the novel biochemistry of this function is not easily encompassed within established views of specificity inherent to typical biochemical assays. 
Table 2. Hsp90 overexpression does not rescue Cdc37 mutants in Drosophila

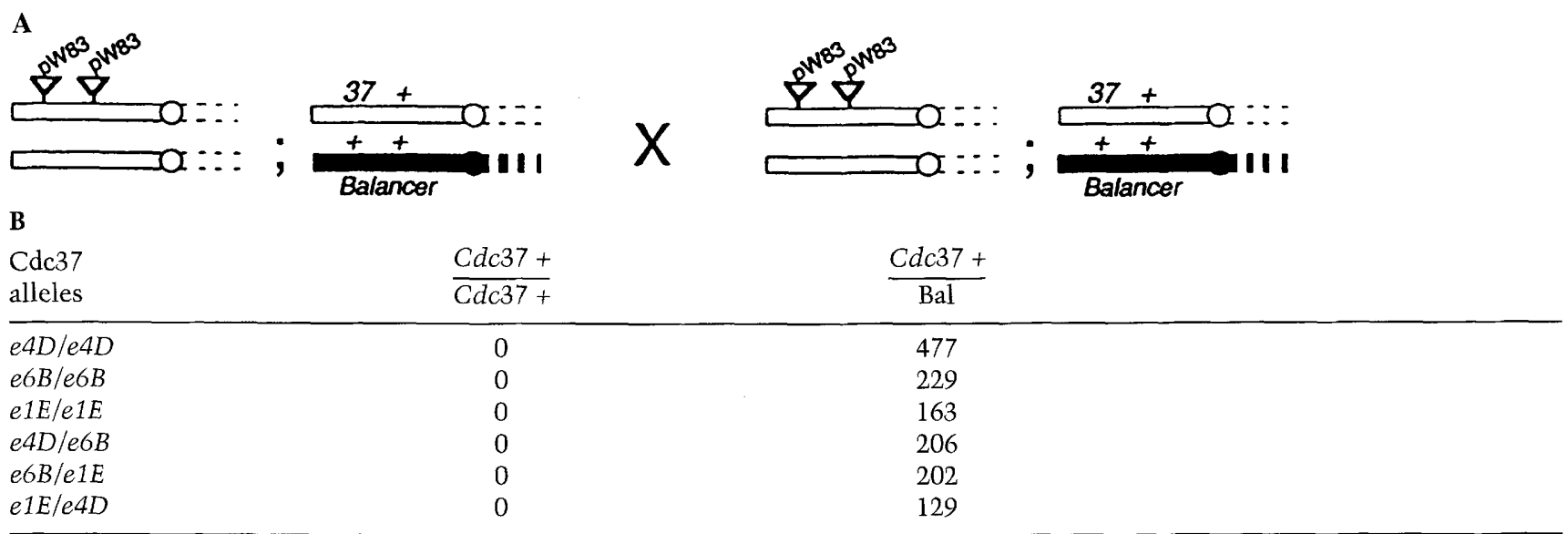

(A) Addition of up to four additional copies of the Hsp83 gene carried in P elements (pW83) did not rescue Cdc37 lethality. To generate $C d c 37$ homozygotes and heteroallelic combinations flies balanced for Cdc37 alleles and containing two copies of pW83 (marked with the eye color marker $\mathrm{w}+$ l were crossed. This generated progeny homozygous for $C d c 37$ and containing from 0 to 4 copies of pW83 as well as the endogenous HSP83 gene $(+) .(B)$ No $w^{+}$flies (containing at least one copy of pW83) survived for any combination of $C d c 37$ alleles tested.

Hsp90 recognizes proteins with certain mature elements of secondary structure, but incomplete tertiary structure (Melnick et al. 1994; Jakob et al. 1995), and associates with its known cellular targets in a highly selective manner. These natural targets are structurally unstable and difficult to study in a highly purified state in vitro. Therefore, the capacity of Hsp90 to interact with and protect non-native model proteins in vitro is a key element in defining its chaperone activity. When a denatured protein is diluted into aqueous buffer, a multiplicity of unstable conformations are formed. Low-affinity interactions with Hsp90 prevent irretrievable aggregation of such proteins but do not promote forward folding. The high stoichiometric ratio of Hsp90 required in these assays may reflect the heterogeneity of the substrate and the low affinity of the interactions but does not invalidate the underlying biochemistry: The function of Hsp90 in such assays is distinct from that of nonchaperone proteins, as well as that of most other chaperones.

\section{Chaperone activity of $\mathrm{Cdc} 37$}

We find that $\mathrm{Cdc} 37$ is a molecular chaperone, by criteria identical to those used to establish Hsp90 as a molecular chaperone. Cdc37 and Hsp90 protect denatured substrates such as $\beta$-galactosidase and firefly luciferase from irretrievable inactivation. They also protect the mature but unstable CKII from inactivation, maintaining its activity under destabilizing conditions. In these assays Cdc37 and Hsp90 display similar concentration dependence, exert very similar maximal effects, and do not require ATP.

To date, $\mathrm{Cdc} 37$ has only been found in association with certain kinases. All kinases share a structurally conserved catalytic domain (Hanks and Hunter 1995), and mutants in Fes that are missing this domain no longer interact with Cdc37 (Nair et al. 1996). Presumably, Cdc37 recognizes a non-native fold characteristic of, but not necessarily restricted to, the catalytic domain of inherently unstable or immature kinases. The chaperone action of $\mathrm{Cdc} 37$ in vitro suggests that in vivo Cdc37 provides conformational support for proteins with structurally unstable domains.

Chaperone activity recently has been found in at least two Hsp90 accessory proteins, Cyp-40 (Duina et al. 1996; Freeman et al. 1996) and FKBP59 (Bose et al. 1996). $\mathrm{Cdc} 37$ chaperone activity is distinct from these. First, in contrast to Cyp-40 and FKBP59, Cdc37 may not form an abundant stable complex with Hsp90 in yeast. A histidine-tagged derivative of $\mathrm{Hsp} 90$, which quantitatively retains Hsp90-associated proteins on nickel columns, retains only a small fraction of the Cdc37 in the cell (Chang and Lindquist 1994 and unpubl.). Second, Cdc37 is at least twice as effective, in terms of the yield of active enzyme recovered, in protecting denatured substrates for reactivation (Bose et al. 1996; Duina et al. 1996; Freeman et al. 1996; direct comparative data by B. Freeman and Y. Kimura, unpubl.). Moreover, unlike the other Hsp90-associated chaperones, Cdc37 appears to act independently of Hsp90 on some substrates. For example, the serine/threonine kinase activity of Mps1, a kinase involved in spindle pole dynamics, is strongly affected by changes in Cdc37 activity but not by changes in Hsp90 that have strong effects on GR and v-Src (Schutz et al. 1997; data not shown). Finally, in mammalian cells, at least $50 \%$ of the Cdc37 target, Cdk4, immunoprecipitates with $\mathrm{Cdc} 37$ in the absence of Hsp90 (Dai et al. 1996). Thus, Cdc37 is uniquely similar to Hsp90, both 
A

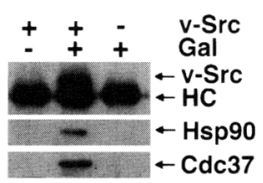

B

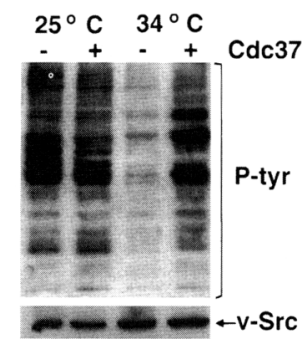

Figure 5. Relationship between $\mathrm{Hsp} 90$ and $\mathrm{Cdc} 37$ in the maturation of v-Src. (A) Hsp90 and Cdc37 coimmunoprecipitate with $\mathrm{v}$-Src in yeast. B) 5457 cells carrying a galactose-regulated v-Src expression plasmid $(+)$ or the vector alone $(-)$ were grown in raffinose and transferred to galactose (Gal) for $2.5 \mathrm{hr}$ to induce $\mathrm{v}$-Src expression. Sepharose beads prebound to antibodies against v-Src were incubated with cell lysates. Immunoprecipitated proteins were separated by SDS-PAGE, transferred to filters, and reacted with antibodies specific to $\mathrm{v}$-Src, Hsp90, and $\mathrm{Cdc} 37$. The positions of $\mathrm{v}-\mathrm{Src}$, immunoglobulin heavy chain $(\mathrm{HC}), \mathrm{Hsp} 90$, and $\mathrm{Cdc} 37$ are indicated. $(B) \mathrm{Cdc} 37$ overexpression restores $\mathrm{v}$-Src phosphotyrosine activity in an Hsp90 mutant. The change in $\mathrm{v}$-Src activity is readily observed as a change in the phosphotyrosine content of total yeast proteins because endogenous tyrosine kinase activity in yeast is very low ( $\mathrm{Xu}$ and Lindquist 1993). A temperature-sensitive hsp90 mutant, hsp $82^{G 170 D}$, carrying a galactose-regulated $\mathrm{v}$-Src expression plasmid was transformed with the vector alone $(-)$ or a highcopy $\mathrm{Cdc} 37$ expression plasmid $(+)$. Cultures grown in raffinose at $25^{\circ} \mathrm{C}$ were transferred to galactose at $25^{\circ} \mathrm{C}$ or $34^{\circ} \mathrm{C}$ for $6 \mathrm{hr}$. Total cellular proteins separated by SDS-PAGE were transferred to membranes and reacted with antibodies specific for phosphotyrosine to assess $\mathrm{v}$-Src activity (P-tyr), or for $\mathrm{v}$-Src to assess $\mathrm{v}$-Src accumulation (v-Src).

in its effectiveness as a chaperone and its independ interaction with targets.

However, $\mathrm{Cdc} 37$ is found in complexes with many of the same cellular targets as Hsp90 and is required for the binding of Hsp90 to Cdk4 (Stepanova et al. 1996). We propose that the specific chaperone functions of $\mathrm{Cdc} 37$ promote or stabilize conformations in $\mathrm{Cdk} 4$ that facilitate recognition by Hsp90. It seems equally plausible that for other substrates, Hsp90 facilitates Cdc37 binding in a similar manner: On certain proteins the two chaperones may interact independently, on others they may mutually reinforce each other. Thus, reducing either Hsp90 or Cdc37 will compromise the activation of $\mathrm{v}-\mathrm{Src}$, but high level overexpression of $\mathrm{Cdc} 37$ can compensate for reduced concentrations of Hsp90. This change in perspective on $\mathrm{Cdc} 37$ is reminiscent of the recent change in perspective on DnaJ. It was once thought that the primary role of DnaJ was to target substrates to DnaK (Hsp70), but DnaJ is now recognized as an equally important chaperone on its own (Georgopoulos and Welch 1993; Schroder et al. 1993).

\section{The complexities of chaperoning unstable proteins}

A multistep, multicomponent chaperone pathway supports the maturation and maintenance of many signal

transducers (Smith 1993; Duina et al. 1996; Nair et al. 1996; Chang et al. 1997). Although both GR and v-Src are highly dependent on Hsp90, only v-Src is highly dependent on Cdc37. It seems likely that different chaperones collaborate to maintain the integrity of signaling pathways by recognizing subtly different features of unstable substrates. The bewildering variety of signaling proteins with which chaperones associate, and the perplexing observation that closely related proteins are independent of these chaperones, likely derives from subtle variations in the stability and structure of the signal transducers themselves. The transient nature of chaperone interactions would preserve a dynamic equilibrium in which inherently unstable signaling targets are maintained in native, or near-native conformations, poised to transduce an activating signal. A picture of the functions of chaperones in signal transduction is beginning to emerge. A major challenge is to determine the breadth and specificity of their functions, not only for signal transduction, but for other cellular processes.

\section{Materials and methods}

Plasmids, strains, and crosses

The URA3 $2 \mu$ plasmid pRS426 (Sikorski and Hieter 1989) was

A

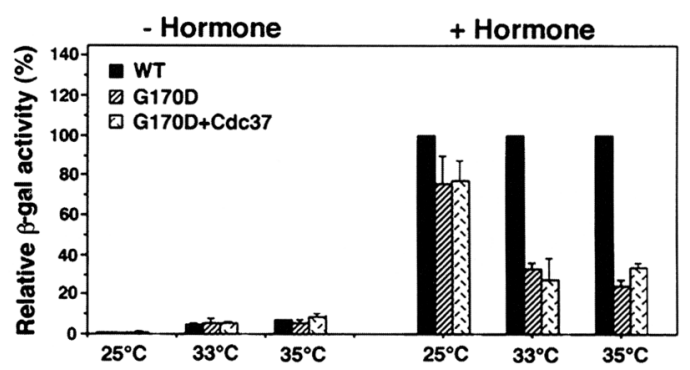

B

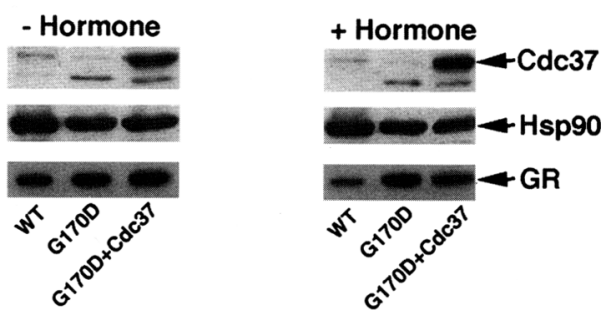

Figure 6. Relationship between $\mathrm{Hsp} 90$ and $\mathrm{Cdc} 37$ in the maturation of GR. (A) Cdc37 overexpression does not restore GR activity in an Hsp90 mutant. Wild-type and $h s p 82^{G 170 D}$ mutant cells carrying a constitutive GR expression plasmid with a linked GRElacZ reporter were transformed with the vector alone or a high-copy expression plasmid for Cdc37. Cultures were grown at $25^{\circ} \mathrm{C}$ and maintained at this temperature, or transferred to semipermissive temperature $\left(33^{\circ} \mathrm{C}\right)$ or nonpermissive temperature $\left(35^{\circ} \mathrm{C}\right)$ with or without the addition of hormone for $6 \mathrm{hr}$. $\beta$-Galactosidase activities, means, and standard deviations, are expressed relative to activities in wild-type cells at each temperature. (B) Accumulation of GR, Hsp90, and $\mathrm{Cdc} 37$ protein. Total cellular proteins from cells treated as described in $A\left(35^{\circ} \mathrm{C}\right)$ were separated by SDS-PAGE, transferred to membranes, and reacted with antibodies specific for $\mathrm{Cdc} 37$, Hsp90, and GR. 
used as a control for the Cdc37 expression derivative pRM37.1 (gift of C. Glover, University of Georgia, Athens). To make pMUsrc, a galactose-regulated $2 \mu$ expression vector for $\mathrm{v}-S r c$, the BamHI-ClaI cleavage fragment of Gallp-v-src (Xu and Lindquist 1993; Kimura et al. 1995) was ligated into pRS426. The $2 \mu$ plasmid $\mathrm{p} 2 \mathrm{~A} / \mathrm{GRGZ}$ expresses GR from a constitutive promoter and $\beta$-galactosidase from a glucocorticoid-response element (Nathan and Lindquist 1995).

Yeast strains are listed in Table 3. The $c d c 37-1$ mutant strain CWY469 (Reed 1980) was backcrossed five times to W303 prior to genetic analyses. To create the strain iLEP1, a plasmid containing HSP82 with a disabled promoter, $\mathrm{pRM}(-110) 82$, was integrated into the HIS3 locus of $\triangle$ PCLD (Borkovich et al. 1989; Chang and Lindquist 1994). Haploid meiotic products carrying both $h s c 82$ and $h s p 82$ deletions were selected.

Drosophila Cdc37 and Hsp83 alleles were provided by G. Rubin (Cutforth and Rubin 1994). Additional Hsp83 alleles were from E. Hafen (Dickson et al. 1996). The transgenic line (w;27 $33 ; 19 / T M 3)$ contained three independent insertions of pW82 (Wohlwill and J. Bonner 1991) located at chromosomal positions 39BC (p33), 58CD (p27), and 96B (p19).

\section{Protein purification}

For the purification of Cdc37, a glutathione $S$-transferase (GST) Cdc37 fusion construct (pGEXCdc37) was created by PCR amplification of $C D C 37$-coding sequence in pRM37.1 using the primers 5'-TTATGATCATGGCCATTGATTACTCTAAGT$3^{\prime}$, and $5^{\prime}$-CTTTATTGATCATTAATT $-3^{\prime}$. The PCR product was cut with $B c l$ and inserted into the $B a m H I$ site of pGEX-3X (Pharmacia). The resulting protein contains a factor Xa cleavage site between GST and Cdc37, and proteolysis releases fulllength $\mathrm{Cdc} 37$ with two extra amino-terminal amino acids, glycine and isoleucine. Recombinant $\mathrm{Cdc} 37$ was purified by glutathione chromatography followed by factor Xa cleavage as recommended (Pharmacia). Cdc37 was purified from contaminating GST and factor $\mathrm{Xa}$ by a second passage through the gluta- thione column followed by anion-exchange chromatography on POROS-HQ or Resource Q. Cdc37 was eluted from these columns as a single peak with $1 \mathrm{M} \mathrm{NaCl}, 20 \mathrm{~mm}$ Tris- $\mathrm{HCl}$ ( $\mathrm{pH}$ 6.9). The peak fractions were dialyzed against $40 \mathrm{mM}$ HEPES (pH 7.5), $20 \mathrm{mM} \mathrm{KCl}$, and $5 \%$ glycerol and stored at $-80^{\circ} \mathrm{C}$.

To estimate the molecular weight of $\mathrm{Cdc} 37,100 \mu \mathrm{g}$ of purified protein was incubated in $100 \mu \mathrm{l}$ of refolding buffer $(25 \mathrm{~mm}$ HEPES at $\mathrm{pH} 7.5,50 \mathrm{~mm} \mathrm{KCl}, 5 \mathrm{~mm} \mathrm{MgCl} \mathrm{m}_{2}, 10 \mathrm{mM}$ DTT, $1 \mathrm{~mm}$ ATP) at $37^{\circ} \mathrm{C}$ for $30 \mathrm{~min}$ and subjected to gel filtration over a Superdex-200 column (Pharmacia-LKB) at $4^{\circ} \mathrm{C}$.

Yeast Hsp90 (Hsp82) was the generous gift of T. Scheibel and J. Buchner (Universität Regensburg, Germany), and yeast Ydj1 (a yeast DnaJ homolog) and Ssa (an Hsp70 protein) were the generous gift of J. Glover. Human Hsp70 and Hdj1 (a human DnaJ homolog) were prepared as described (Freeman and Morimoto 1996). For CKII assays, Hsp90 was purified from mouse lymphoma L5178Y cells or rat livers, and CKII was purified from porcine testis, as described (Miyata and Yahara 1992, 1995).

\section{Chaperone assays}

Purified yeast Cdc37 and Hsp82 were tested for chaperone activity in $\beta$-galactosidase refolding assays as described for mammalian Hsp90 (Freeman and Morimoto 1996). Firefly luciferase assays were conducted in the same manner, substituting ureadenatured fire fly luciferase (Sigma, cat. no. G5635) for guanidinium-denatured $\beta$-galactosidase (Sigma, cat. no. L1759). Luciferase assays were performed with yeast $\mathrm{Ydj} 1$ rather than human Hdj1.

Maintenance of CKII was assayed with $1 \mu \mathrm{M} \mathrm{Cdc} 37$ and/or 1 $\mu \mathrm{M}$ Hsp90 as described (Miyata and Yahara 1992), with the following modifications. Purified CKII (20 ng) was diluted into 13 $\mu \mathrm{l}$ of buffer containing Cdc37 and/or Hsp90 in $7.7 \mathrm{~mm}$ Tris, 15.4 $\mathrm{mM} \mathrm{NaCl}, 3.1 \mathrm{~mm} \mathrm{KCl}, 0.31 \mathrm{~mm}$ EDTA, 2.3\% glycerol, $0.15 \mathrm{~mm}$ DTT, and $6.2 \mathrm{mM}$ HEPES ( $\mathrm{pH} 7.4)$. The mixture was incubated for $60 \mathrm{~min}$ at $30^{\circ} \mathrm{C}$ and $10 \mu \mathrm{l}$ of a solution containing 2.25 $\mathrm{mg} / \mathrm{ml}$ of dephosphorylated casein (Sigma), $0.17 \mathrm{mBq}$ (185 Bq/

Table 3. Yeast strains used in this study

\begin{tabular}{|c|c|c|}
\hline Strain & Genotype & Reference \\
\hline W303 & MATa ade2-1 can1-100 his3-11,15 leu2-3,112 trp1-1 ura3-1 & $\begin{array}{l}\text { R. Rothstein (Columbia University, } \\
\text { New York, NY) }\end{array}$ \\
\hline CLD82 & MATa ade2-1 can1-100 his3-11,15 lew2-3,112 trp1-1 ura3-1 $\Delta$ hsc82::LEU2 & Borkovich et al. (1989) \\
\hline $\mathrm{P} 82 \mathrm{a}$ & $\begin{array}{l}\text { MATa ade2-1 can1-100 his3-11,15 leu2-3,112 trp1-1 ura3-1 } \Delta \text { hsc82::LEU2 } \\
\quad \text { Shsp82::LEU2 (pTGpd/P82) }\end{array}$ & Nathan and Lindquist $(1995\}$ \\
\hline G170Da & $\begin{array}{l}\text { MATa ade2-1 can1-100 his3-11,15 leu2-3,112 trp1-1 ura3-1 } \Delta \text { hsc82::LEU2 } \\
\text { Shsp82::LEU2 (pTGpd/T1-101) }\end{array}$ & Nathan and Lindquist (1995) \\
\hline A $41 \mathrm{Va}$ & $\begin{array}{l}\text { MATa ade2-1 can1-100 his3-11,15 leu2-3,112 trp1-1 ura3-1 } 4 \text { hsc82::LEU2 } \\
\text { Ahsp82::LEU2 (pTGpd/T1-40) }\end{array}$ & Nathan and Lindquist (1995) \\
\hline G81Sa & $\begin{array}{l}\text { MATa ade2-1 can1-100 his3-11,15 leu2-3,112 trp1-1 ura3-1 } \Delta \text { hsc82::LEU2 } \\
\quad \text { Shsp82::LEU2 (pTGpd/T1-15) }\end{array}$ & Nathan and Lindquist (1995) \\
\hline G313Sa & $\begin{array}{l}\text { MATa ade2-1 can1-100 his3-11,15 leu2-3,112 trp1-1 ura3-1 } \triangle \text { hsc82::LEU2 } \\
\text { Ahsp82::LEU2 (pTGpd/T4-47) }\end{array}$ & Nathan and Lindquist (1995) \\
\hline $\mathrm{E} 381 \mathrm{Ka}$ & $\begin{array}{l}\text { MATa ade2-1 can1-100 his3-11,15 leu2-3,112 trp1-1 ura3-1 } \Delta \text { hsc82::LEU2 } \\
\text { Shsp82::LEU2 (pTGpd/T4-19) }\end{array}$ & Nathan and Lindquist $(1995)$ \\
\hline $\mathrm{A} 587 \mathrm{Ta}$ & $\begin{array}{l}\text { MATa ade2-1 can1-100 his3-11,15 leu2-3,112 trp1-1 ura3-1 } \Delta \text { hsc82::LEU2 } \\
\text { Shsp82::LEU2 (pTGpd/T1-66) }\end{array}$ & Nathan and Lindquist $\{1995\}$ \\
\hline T221a & $\begin{array}{l}\text { MATa ade2-1 can1-100 his3-11,15 leu2-3,112 trp1-1 ura3-1 } \Delta \text { hsc82::LEU2 } \\
\text { Shsp82::LEU2 (pTGpd/T3-142) }\end{array}$ & Nathan and Lindquist (1995) \\
\hline CWY469 & MATa ade1 his2 leu2-3,112 trp1-50 ura3Dns bar1D cdc37-1 & $\begin{array}{l}\text { S.I. Reed (Scripps Research Institute, } \\
\text { La Jolla, CA) }\end{array}$ \\
\hline WC37A & MATa ade2-1 can1-100 his3-11,15 leu2-3,112 trp1-1 ura3 cdc37-1 & this study \\
\hline ilepla & $\begin{array}{l}\text { MATa ade2-1 can1-100 his3-11,15::pRS303-F3::HIS3 leu2-3,112 trp1-1 } \\
\text { ura3-1 } \Delta \text { hsc82::LEU2 } \Delta \text { sp 82::LEU2 }\end{array}$ & this study \\
\hline BJ5457 & 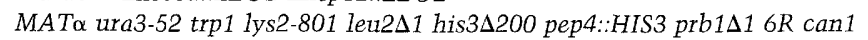 & Jones (1991) \\
\hline
\end{tabular}


mmolel of $\left[\gamma^{32} \mathrm{P}\right] \mathrm{ATP}+0.2 \mathrm{mM}$ cold ATP, $6 \mathrm{~mm}$ Tris- $\mathrm{HCl}$, and $33 \mathrm{~mm}$ MOPS; $40 \mathrm{~mm} \mathrm{MgCl}$ (pH 7.3), was added to start the phosphorylation reaction, which was kept at $30^{\circ} \mathrm{C}$ for an additional $30 \mathrm{~min}$. Reactions were terminated with SDS sample buffer and boiled for $5 \mathrm{~min}$. After SDS-PAGE, the incorporation of radioactive phosphate into casein was visualized by autoradiography.

\section{Immunoprecipitation}

Yeast cultures containing pMUsrc or pRS426 were induced by the addition of galactose to $4 \%$. Immunoprecipitation of $\mathrm{v}$-Src was performed as described (Kimura et al. 1995) except that cell extracts $(0.7-1.2 \mathrm{mg}$ of protein) were mixed with $20 \mu \mathrm{l}$ of Gamma Bind Plus Sepharose (Quality Biotech) that had been preincubated with $4 \mu \mathrm{l}$ of anti-Src antibody. Elutes and cell lysate were separated by SDS-PAGE, transferred to Immobilon membranes, and reacted sequentially with antibodies specific to v-Src (LA074, Quality Biotech), Hsp90 (Borkovich et al. 1989), and Cdc37. Rabbit anti-yeast $\mathrm{Cdc} 37$ antibody was a gift from S. Reed (Scripps Research Institute, La Jolla, CA).

\section{Analysis of $V$-Src and $G R$}

Cultures containing Gallp-v-src plus pRM37.1 or pRS426 were grown on SRaf minus uracil and histidine. Induction of $\mathrm{v}$-Src and immunological analysis were performed according to Nathan and Lindquist (1995). Cultures containing p2A/GRGZ plus pRM37.1 or pRS426 were grown on SD minus uracil and adenine. GR activity was induced for $6 \mathrm{hr}$ with hormone [10 $\mu \mathrm{M}$ deoxycorticosterone (DOC)l, and assays were performed according to Nathan and Lindquist (1995).

\section{Acknowledgments}

We are grateful to J. Buchner, T. Scheibel, and J. Glover for the gift of purified proteins, S. Reed for $c d c 37-1$ strain and $\mathrm{Cdc} 37$ antibody, C. Glover for a Cdc37 expression plasmid, G. Rubin, E. Hafen, and J. Bonner for Drosophila stocks, M. Winey, A Shutz , F. Boschelli, and J. Buchner for sharing information prior to publication, Jia-Jia Liu, Melissa Vos, and D. Bimston, for technical assistance, and D. Nathan and J. Glover for advice. This work was supported by the Howard Hughes Medical Institute and The National Institutes of Health (NIH), B.F. was supported by an NIH training grant, Y.K. and S.R. were supported by the Howard Hughes Medical Institute, and L.Y. by an NIH postdoctoral fellowship.

The publication costs of this article were defrayed in part by payment of page charges. This article must therefore be hereby marked "advertisement" in accordance with 18 USC section 1734 solely to indicate this fact.

\section{References}

Bohen, S.P. and K.R. Yamamoto. 1994. Modulation of steroid receptor signal transduction by heat shock proteins. In The biology of heat shock proteins and molecular chaperones (ed. R. Morimoto, A. Tissieres, and C. Georgopoulos), pp. 313-334, Cold Spring Harbor Laboratory Press, Cold Spring Harbor, NY.

Borkovich, K.A., F.W. Farrelly, D.B. Finkelstein, J. Taulien, and S. Lindquist. 1989. Hsp82 is an essential protein that is required in higher concentrations for growth of cells at higher temperatures. Mol. Cell Biol. 9: 3919-3930.

Bose, S., T. Weikl, H. Bugl, and J. Buchner. 1996. Chaperone function of Hsp90-associated proteins. Science 274: 17151717.

Brugge, J.S. 1986. Interaction of the Rous sarcoma virus protein pp60src with the cellular proteins pp50 and pp90. Curr. Top. Microbiol. Immunol. 123: 1-22.

Brugge, J.S., E. Erikson, and R.L. Erikson. 1981. The specific interaction of the Rous sarcoma virus transforming protein, pp60src, with two cellular proteins. Cell 25: 363-372.

Chang, H.-C., D.F. Nathan, and S. Lindquist. 1997. In vivo analysis of the Hsp90 cochaperone Sti1 (p60). Mol. Cell Biol. 17: 318-325.

Chang, H.-C. and S. Lindquist. 1994. Conservation of Hsp90 macromolecular complexes in Saccharomyces cerevisiae. $J$. Biol. Chem. 269: 24983-24988.

Cutforth, T. and G.M. Rubin. 1994. Mutations in Hsp83 and $c d c 37$ impair signaling by the sevenless receptor tyrosine kinase in Drosophila. Cell 77: 1027-1036.

Dai, K., R. Kobayashi, and D. Beach. 1996. Physical interaction of mammalian CDC37 with CDK4. I. Biol. Chem. 271: 22030-22034.

Dey, B., J. Lightbody, and F. Boschelli. 1996. CDC37 is required for p60 ${ }^{\mathrm{v}-\mathrm{src}}$ activity in yeast. Mol. Biol. Cell 7: 1405-1417.

Dickson, B.I., A. van der Straten, M. Dominguez, and E. Hafen. 1996. Mutations modulating raf signaling in Drosophila eye development. Genetics 142: 163-171.

Dougherty, J.J., D.A. Rabideau, A.M. Iannotti, W.P. Sullivan, and D.O. Toft. 1987. Identification of the $90 \mathrm{kDa}$ substrate of rat liver type II casein kinase with the heat shock protein which binds steroid receptors. Biochim. Biophys. Acta 927: 74-80.

Duina, A.A., H.-C.J. Chang, J.A. Marsh, S. Lindquist, and R.F. Garber. 1996. A cyclophilin function in Hsp90-dependent signal transduction. Science 274: 1713-1715.

Ellis, J. 1987. Proteins as molecular chaperones. Nature 328: 378-379.

Ferguson, I., J.Y. Ho, T.A. Peterson, and S.I. Reed. 1986. Nucleotide sequence of the yeast cell division cycle start genes CDC28, CDC36, CDC37, and CDC39, and a structural analysis of the predicted products. Nucleic Acids Res. 14: 6681-6697.

Freeman, B.C. and R.I. Morimoto. 1996. The human cytosolic molecular chaperones hsp90, hsp70 (hsc70) and hdj-1 have distinct roles in recognition of non-native protein and protein refolding. EMBO I. 15: 2969-2979.

Freeman, B.C., D.O. Toft, and R.I. Morimoto. 1996. Molecular chaperone machines: Chaperone activities of the cyclophilin CYP-40 and the steroid aporeceptor associated protein, p23. Science 274: 1718-1720.

Georgopoulos, C. and W.J. Welch. 1993. Role of the major heat shock proteins as molecular chaperones. In Annu. Rev. Cell Biol. (ed. G. E. Palade), pp. 601-634.

Gerber, M.R., A. Farrell, R.J. Deshaies, I. Herskowitz, and D.O. Morgan. 1995. Cdc37 is required for association of the protein kinase Cdc28 with G1 and mitotic cyclins. Proc. Natl. Acad. Sci. 92: 4651-4655.

Hanks, S.K. and T. Hunter. 1995. The eukaryotic protein kinase superfamily: Kinase (catalytic) domain structure and classification. FASEB J. 9: 576-596.

Hartson, S.D. and R.L. Matts. 1994. Association of Hsp90 with cellular Src-family kinases in a cell-free system correlates with altered kinase structure and function. Biochemistry 33: 8912-8920.

Jakob, U. and J. Buchner. 1994. Assisting spontaneity: The role of Hsp90 and small Hsps as molecular chaperones. Trends Biochem. Sci. 19: 205-211.

Jakob, U., H. Lilie, I. Meyer, and J. Buchner. 1995. Transient 
interaction of Hsp90 with early unfolding intermediates of citrate synthase. Implications for heat shock in vivo. J. Biol. Chem. 270: 7288-7294.

Jones, E. 1991. Tackling the protease: A problem in Saccharomyces cerevisiae. Methods Enzymol. 194: 428-453.

Kimura, Y., I. Yahara, and S. Lindquist. 1995. Role of the protein chaperone YDJ1 in establishing Hsp90-mediated signal transduction pathways. Science 268: 1362-1365.

Lindsley, D.L. and G.G. Zimm. 1992. The genome of Drosophila melanogaster. Academic Press, New York, NY.

McCann, R. and C.V.C. Glover. 1995. Evidence for the physiological interaction of yeast $\mathrm{Cdc} 37$ and casein kinase II. Mol. Biol. Cell (Supp.) 6: 133a.

Melnick, J., J.L. Dul, and Y. Argon. 1994. Sequential interaction of the chaperones BiP and GRP94 with immunoglobin chains in the endoplasmic reticulum. Nature 370: 373-375.

Miyata, Y. and I. Yahara. 1992. The 90-kDa heat shock protein, HSP90, binds and protects casein kinase II from self-aggregation and enhances its kinase activity. I. Biol. Chem. 267: 7042-7047.

. 1995. Interaction between casein kinase II and the 90kDa stress protein, HSP90. Biochemistry 34: 8123-8129.

Nair, S.C., E.J. Toran, R.A. Rimerman, S. Hjermstad, T.E. Smithgall, and D.F. Smith. 1996. A pathway of multi-chaperone interactions common to diverse regulatory proteins: Estrogen receptor, Fes tyrosine kinase, heat shock transcription factor HSF1, and the arylhydrocarbon receptor. Cell Stress Chaperones 1: 237-250.

Nathan, D.F. and S. Lindquist. 1995. Mutational analysis of Hsp90 function: Interactions with a steroid receptor and a protein kinase. Mol. Cell Biol. 15: 3917-3925.

Picard, D., B. Khursheed, M.J. Garabedian, M.G. Fortin, S. Lindquist, and K.R. Yamamoto. 1990. Reduced levels of hsp90 compromise steroid receptor action in vivo. Nature 348: $166-168$.

Reed, S.I. 1980. The selection of S. cerevisiae mutants defective in the start event of cell division. Genetics 95: 561-577.

Reed, S.I., M.A. de Barros Lopes, J. Freemason, J.A. Hadwiger, J.Y. Ho, R. Horwitz, C.A. Jones, A.T. Lorincz, M.D. Mendenhall, T.A. Peterson, S.L. Richardson, and C. Wittenberg. 1985. Genetic and molecular analysis of division control in yeast. Cold Spring Harbor Symp. Quant. Biol. 50: 627-634.

Rutherford, S.L. and C.S. Zuker. 1994. Protein folding and the regulation of signaling pathways. Cell 79: 1129-1132.

Schroder, H.T., T. Langer, F.-U. Hartl, and B. Bukau. 1993. DnaK, Dnal, GrpE form a cellular chaperone machinery capable of repairing heat-induced protein damage. EMBO $J$. 12: 4137-4144.

Schutz, A.R., T.H. Giddings, Jr., E. Steiner, and M. Winey. 1997. The yeast CDC37 gene interacts with MPS1 and is required for proper execution of spindle pole body duplication. J. Cell Biol. 136: 969-982.

Shaknovich, R., G. Shue, and D.S. Kohtz. 1992. Conformational activation of a basic helix-loop-helix protein (MyoD1) by the C-terminal region of murine HSP90 (HSP84). Mol. Cell Biol. 12: 5059-5068.

Sikorski, R.S. and P. Hieter. 1989. A system of shuttle vectors and yeast host strains designed for efficient manipulation of DNA in Saccharomyces cerivisiae. Genetics 122: 19-27.

Smith, D.S. 1993. Dynamics of heat shock protein 90-progesterone receptor binding and the disactivation loop model for steroid receptor complexes. Mol. Endocrinol. 7: 1418-1429.

Smith, D.S. and D.O. Toft. 1993. Steroid receptors and their associated proteins. Mol. Endocrinol. 7: 4-11.

Stancato, L.F., Y.H. Chow, K.A. Hutison, G.H. Perdew, R. Jove, and W.B. Pratt. 1993. Raf exists in a native heterocomplex with Hsp90 and p50 that can be reconstituted in a cell-free system. J. Biol. Chem. 268: 21711-21716.

Stepanova, L., X. Leng, S.B. Parker, and W.J. Harper. 1996. Mammalian $\mathrm{p} 50^{\mathrm{Cdc} 37}$ is a protein kinase-targeting subunit of Hsp90 that binds and stabilizes Cdk4. Genes \& Dev. 10: 1491-1502.

Wartmann, M. and R.J. Davis. 1994. The native structure of the activated Raf protein kinase is a membrane-bound multisubunit complex. J. Biol. Chem. 269: 6695-6701.

Whitelaw, M.L., K. Hutchison, and G.H. Perdew. 1991. A 50$\mathrm{kDa}$ cytosolic protein complexed with the $90-\mathrm{kDa}$ heat shock protein (hsp90) is the same protein complexed with $\mathrm{v}$-Src hsp90 in cells transformed by the Rous sarcoma virus. J. Biol. Chem. 266: 16436-16440.

Wiech, H., J. Buchner, R. Zimmermann, and U. Jakob. 1992. Hsp90 chaperones protein folding in vitro. Nature 358: 169 170.

Wohlwill, A.D. and J.J. Bonner. 1991. Genetic analysis of chromosome region 63 of Drosophila melanogaster. Genetics 128: 763-775.

$\mathrm{Xu}, \mathrm{Y}$. and S. Lindquist. 1993. Heat-shock protein hsp90 governs the activity of v-Src kinase. Proc. Natl. Acad. Sci. 90: 70747078 .

Ziemiecki, A., M.G. Catelli, I. Joab, and B. Moncharmont. 1986. Association of the heat shock protein hsp90 with steroid hormone receptors and tyrosine kinase oncogene products. Biochem. Biophys. Res. Commun. 138: 1298-1307. 


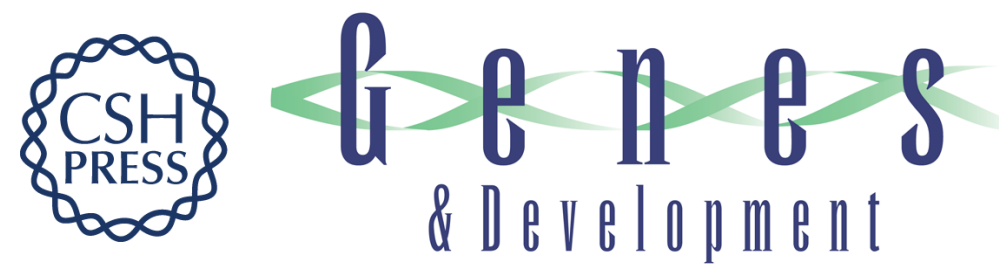

\section{Cdc37 is a molecular chaperone with specific functions in signal transduction.}

Y Kimura, S L Rutherford, Y Miyata, et al.

Genes Dev. 1997, 11:

Access the most recent version at doi:10.1101/gad.11.14.1775

References This article cites 47 articles, 25 of which can be accessed free at: http://genesdev.cshlp.org/content/11/14/1775.full.html\#ref-list-1

License

Email Alerting

Service

Receive free email alerts when new articles cite this article - sign up in the box at the top right corner of the article or click here.

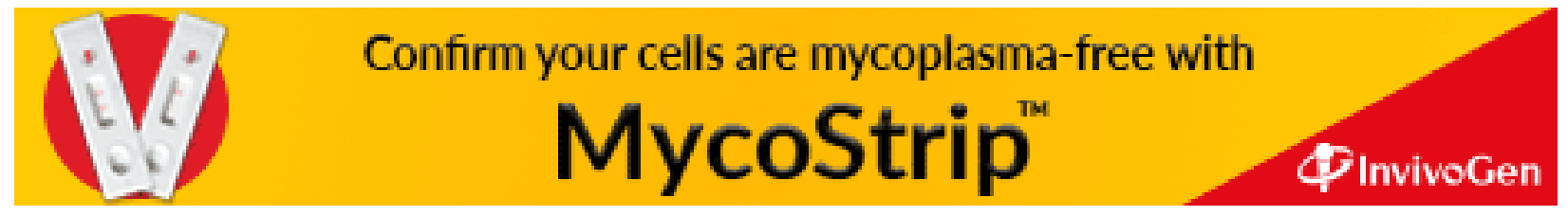

